\title{
ГЕНДЕРНІ АСПЕКТИ КАРДІОПРОТЕКТОРНОЇ ЕФЕКТИВНОСТІ МЕЛАТОНІНУ ПРИ РОЗВИТКУ АДРЕНАЛІНІНДУКОВАНОГО НЕКРОЗУ МІОКАРДА НА ТЛІ ПЕРМАНЕНТНОГО ОСВІТЛЕННЯ
}

Вступ. Світловий десинхроноз є важливим фрактором ризику розвитку ішемічної хвороби серця, яка частіше виникає в чоловіків. Ушкодження міокарда за умов стресу, викликаного порушенням режиму освітлення (його надлишком), призводить до значного дефріциту ендогенного мелатоніну, який має антиоксидантні властивості. Це дозволяє прогнозувати зменшення негативного впливу стресу або катехоламінів на серце за умов перманентного освітлення при застосуванні екзогенного мелатоніну. На сьогодні недостатньо вивчено питання гендерної відмінності кардіопротекторних ефектів мелатоніну при порушенні активності пінеальної залози.

Мета дослідження-вивчити кардіопротекторну ефрективність екзогенного мелатонінупри розвитку некрозу міокарда на тлі перманентного освітлення залежно від статі.

Методи дослідження. У міокарді шлуночків самців і самиць щурів визначали відсоток некротизованих кардіоміоцитів, активність пероксидного окиснення ліпідів та антиоксидантної системи при ушкодженні адреналіном. Некроз міокарда викликали шляхом введення адреналіну (0,5 мг/кг, внутрішньом'язово) на тлі перманентного освітлення (10 днів освітлення 500 люкс, 24 год/добу). Групу контролю становили тварини, які перебували в умовах зміни циклів день/ніч (12 год освітлення 500 люкс/12 год освітлення 0,5-1,0 люкс). Мелатонін (5 мг/ка, інтраперитонеально) з метою корекції вводили за 1 год до ін'єкції адреналіну.

Результати й обговорення. При застосуваннімелатоніну розвиток некрозуміокарда характеризувався меншим відсотком некротизованих кардіоміоцитів, нижчою, ніж без корекції, активацією пероксидного окиснення ліпідів, більшою активністю супероксиддисмутази і глутатіонпероксидази. Про кращу збалансованість прооксидантно-антиоксидантних процесів свідчило вище, ніж без корекції, значення антиоксидантно-прооксидантного індексу, особливо в самиць. Ця закономірність демонструвала позитивний вплив екзогенного мелатоніну та непрямо підтверджувалайого дефріцит за умов перманентного освітлення.

Висновок. Застосування екзогенного мелатоніну для корекції його дефіциту при перманентному освітленні має позитивний вплив на розвиток адреналініндукованого некрозу міокарда, що підтверджується нижчою, ніж без такої корекції, активацією пероксидного окиснення ліпідів, менш вираженою депресією системи антиоксидантів, меншим відсотком некротизованих кардіоміоцитів. Самиці щурів більш чутливі до позитивного впливу екзогенного мелатоніну порівняно із самцями.

КЛЮЧОВІ СЛОВА: перманентне освітлення; некроз міокарда; вільнорадикальне окиснення; статеві відмінності.

ВСТУП. Домінування серцево-судинної патології свідчить про збереження актуальності наукових досліджень у галузі експериментальної кардіології. Серед фракторів ризику розвитку ішемічної хвороби серця та інфраркту міокарда чільне місце займає стрес, викликаний порушенням світлового режиму. Світловий десинхроноз став частиною життя сучасної людини [1]. Швидка зміна часових поясів, тривала робота за комп'ютером, у приміщеннях 3 потужним освітленням (офісні приміщення, в томуж числі (с Г. О. Безкоровайна, І. М. Кліщ, М. Р. Хара, 2020. й лікарень) створюють підґрунтя для порушення циркадіанних ритмів, активності пінеальної залози, в результаті чого виникає значний десріцит мелатоніну. Його кардіопротекторні есректи, зокрема антиоксидантні, довело багато дослідників [2, 3]. Серед механізмів кардіопротекції важливу роль відводять впливу на мітохондрії, стабілізації їх мембран для зменшення участі в розвитку окисного стресу $[4,5]$. Водночас, зважаючи на гендерну відмінність за показниками захворюваності на інфраркт міокарда, недостатньо активно вивчають питання 
відмінностей кардіопротекторної ефективності мелатоніну залежно від статі.

Мета дослідження - вивчити кардіопротекторну ефективність екзогенного мелатоніну при розвитку некрозу міокарда на тлі перманентного освітлення залежно від статі.

МЕТОДИ ДОСЛІДЖЕННЯ. ДослідИ Виконано на білих щурах масою 220-270 г. Адреналініндукований некроз міокарда (НМ) моделювали шляхом введення адреналіну (0,5 мг/кг, внутрішньом'язово). До цього моменту тварини 10 діб перебували в умовах постійного освітлення (500 люкс) усі 24 год на добу. Основні дослідження, які передбачали визначення в міокарді шлуночків вмісту продуктів пероксидного окиснення ліпідів (ПОЛ) таактивностіантиоксидантної системи (АОС), проводили через 1 і 24 год після введення адреналіну (початок та пік некрозоутворення). Активність ПОЛ оцінювали за вмістом дієнових кон'югатів (ДК), малонового діальдегіду (МДА) [6, 7], стан АОС - за активністю супероксиддисмутази (СОД) [8], каталази (КАТ) [9], глутатіонредуктази (ГР) та глутатіонпероксидази (ГП) [10], вмістом SH-груп [11]. 3а відношенням активності КАТ та вмісту МДА визначали прооксидантно-антиоксидантний індекс (АПІ). Мелатонін (МЕЛ, 5 мг/кг, інтраперитонеально) 3 метою кардіопротекції вводили за 1 годдоін'єкції адреналіну[12]. Кардіопротекторну еорективність МЕЛ оцінювали за відсотком некротизованих кардіоміоцитів (ВНК) у зрізах міокарда шлуночків (5-6 мкм), пофрарбованих за Гейденгайном. Отримані результати порівнювали 3 аналогічними у тварин, які перебували в умовах світлового балансу (12 год освітлення 500 люкс і 12 год освітлення 0,51,0 люкс) та перманентного освітлення. Евтаназію щурів проводили під тіопенталовим наркозом. Для статистичної обробки даних використовували комп'ютерну програму Microsoft Excel ХР (США). Усі експерименти виконували 3 дотриманням правил біоетики

РЕЗУЛЬТАТИ Й ОБГОВОРЕННЯ. ДОСЛідження активності ПОЛ при розвитку НМ на тлі МЕЛ показало позитивний ефект препарату. Попри підвищення вмісту ДК та МДА інтенсивність процесу була значно меншою, ніж без такої корекції. Якщо за умов перманентного освітлення вміст ДК у самців на 1 та 24 год збільшився проти контролю у 2,0 і 3,8 раза ( $p<0,001)$, МДА - в 3,2 та 4,6 раза ( $<<0,001)$, то при застосуванні МЕЛ приріст ДК становив, відповідно, 1,9 і 3,7 раза ( $p<0,001)$, а МДА - 3,7 та 5,4 раза ( $p<0,001)$. Як показав аналіз показників, при використанні МЕЛ вміст МДА збільшувався суттєвіше, ніж без такої корекції, що не відповідало анонсованій кардіопротекції, яку спостерігали інші автори [13]. Варто зазначити, що при застосуванні МЕЛ відсоток некротизованих кардіоміоцитів, за даними морфометричного аналізу, був достовірно меншим, ніж без корекції, у 2,0 та 1,8 раза ( $p<0,001)$ відповідно на 1 і 24 год спостереження. Цей, здавалося б, дисонанс можна пояснити тим, що за умов гіперкатехоламінемії (стресова катаболічна фраза) активується синтез ейкозаноїдів з базових продуктів ПОЛ, якими є ДК та МДА. А такі біохімічні реакції $є$ проявом генетичного запрограмованого механізму швидкої адаптації (загальний неспецифрічний адаптаційний синдром) [14]. Тобто в змодельованих нами умовах можна думати про менший ступінь стресу, який переживали тварини, що попередньо отримували МЕЛ, та нижчу активність синтезу ейкозаноїдів з базових метаболітів ПОЛ. У самиць аналогічний аналіз показав, що за перманентного освітлення вміст ДК на 1 та 24 год розвитку НМ збільшився, відповідно, у 2,3 і 3,0 рази $(p<0,001)$, при застосуванні МЕЛ - в 1,9 та 3,3 раза ( $p<0,001)$. Вміст МДА за відсутності корекції підвищився, відповідно, в 3,3 і 4,5 раза ( $p<0,001)$, а при використанні МЕЛ - у 3,4 та 4,7 раза $(p<0,001)$.

Обрахунок ВНК у самиць також підтвердив кардіопротекторний ефект МЕЛ, адже при застосуванні препарату цей показник був достовірно меншим, ніж без корекції, зокрема на 1 год розвитку НМ - в 2,1 раза ( $p<0,001)$, а на 24 год в 1,9 раза $(\mathrm{p}<0,001)$. Тобто вищезазначене підтвердило ефективність використаної кардіопротекторної дози мелатоніну, що узгоджувалося 3 даними інших дослідників [13]. Крім того, отримані дані непрямо продемонстрували суттєвий десріцит ендогенного мелатоніну за умов перманентного освітлення.

Порівняно з показниками тварин, які перебували в умовах світлового балансу, вміст ДК та МДА при розвитку некрозу міокарда на тлі МЕЛ мав незначні відмінності. Зокрема, в самців при застосуванні МЕЛ вміст ДК був аналогічним у всі періоди спостереження. У самиць на 24 год розвитку некрозу міокарда на тлі МЕЛ він був більшим, ніж за світлового балансу, на $9 \%$ $(p<0,05)$. При цьому вміст МДА виявився меншим. У самців на 1 та 24 год розвитку НМ він був нижчим, ніж за світлового балансу, в аналогічні періоди спостереження - на 8 і $7 \%(p<0,05)$ відповідно ( $p<0,05)$, а в самиць - на $11(p<0,05)$ і $9 \%(p<0,05)$, що на метаболічному рівні також підтвердило кардіопротекторну ефективність мелатоніну й узгоджувалося 3 даними авторів, які застосовували аналогічну дозу препарату в щурів (табл. 1) [13, 14]. 
Таблиця 1 - Вміст продуктів пероксидного окиснення ліпідів у міокарді щурів

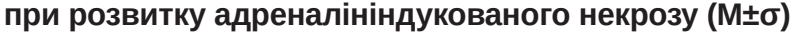

\begin{tabular}{|c|c|c|c|c|}
\hline Показник & Стать & $\begin{array}{c}\text { Контроль } \\
(\mathrm{n}=6)\end{array}$ & $\begin{array}{c}\text { НM (1 год) } \\
(n=6)\end{array}$ & $\begin{array}{c}\text { НМ (24 год) } \\
(n=6)\end{array}$ \\
\hline \multicolumn{5}{|c|}{ Світловий баланс } \\
\hline \multirow{2}{*}{$\begin{array}{l}\text { ДК, } \\
\text { ум. од./кг }\end{array}$} & $\sigma^{x}$ & $0,17 \pm 0,01$ & $0,39 \pm 0,02^{*}$ & $0,71 \pm 0,04^{\star *}$ \\
\hline & 우 & $0,16 \pm 0,01$ & $0,34 \pm 0,02^{*}$ & $0,57 \pm 0,03^{\text {*\# }}$ \\
\hline \multirow{2}{*}{$\begin{array}{l}\text { МДА, } \\
\text { мкМоль/кг }\end{array}$} & $0^{x}$ & $1,24 \pm 0,03$ & $3,79 \pm 0,12^{*}$ & $5,93 \pm 0,18^{\star \#}$ \\
\hline & 우 & $1,33 \pm 0,05$ & $3,44 \pm 0,06^{*}$ & $4,67 \pm 0,09^{\star \#}$ \\
\hline \multicolumn{5}{|c|}{ Перманентне освітлення } \\
\hline \multirow{2}{*}{$\begin{array}{l}\text { ДК, } \\
\text { ум. од./кг }\end{array}$} & $0^{x}$ & $0,28 \pm 0,02^{\wedge}$ & $0,56 \pm 0,01 * \wedge$ & $1,07 \pm 0,07^{\star \wedge \#}$ \\
\hline & 우 & $0,24 \pm 0,02^{\wedge}$ & $0,54 \pm 0,03^{\star \wedge}$ & $0,73 \pm 0,03^{\star \wedge \#}$ \\
\hline \multirow{2}{*}{$\begin{array}{l}\text { МДА, } \\
\text { мкмоль/кг }\end{array}$} & $0^{x}$ & $1,92 \pm 0,13^{\wedge}$ & $6,07 \pm 0,15^{\star \wedge}$ & $8,83 \pm 0,15^{\star \wedge \#}$ \\
\hline & 우 & $1,68 \pm 0,11^{\wedge}$ & $5,55 \pm 0,13^{\star \wedge}$ & $7,63 \pm 0,19^{\star \wedge \#}$ \\
\hline \multicolumn{5}{|c|}{ Перманентне освітлення+мелатонін } \\
\hline \multirow{2}{*}{$\begin{array}{l}\text { ДК, } \\
\text { ум. од./кг }\end{array}$} & $0^{x}$ & $0,22 \pm 0,01$ & $0,41 \pm 0,01^{\star \#}$ & $0,73 \pm 0,02^{\star \#}$ \\
\hline & 우 & $0,19 \pm 0,01$ & $0,37 \pm 0,01^{\star \#}$ & $0,62 \pm 0,02^{\star \wedge \#}$ \\
\hline \multirow{2}{*}{$\begin{array}{l}\text { МДА, } \\
\text { мкмоль/кг }\end{array}$} & $\frac{1}{0^{x}}$ & $1,21 \pm 0,02$ & $4,44 \pm 0,04^{\star \wedge \#}$ & $6,57 \pm 0,14^{\star \wedge \#}$ \\
\hline & q & $1,25 \pm 0,02$ & $4,22 \pm 0,03^{\star \wedge \#}$ & $5,83 \pm 0,15^{\star \wedge \#}$ \\
\hline
\end{tabular}

Примітка. Тут і в таблицях 2, 3: * - достовірна $(p \leq 0,05)$ відмінність відносно контролю; ^ - відносно показника тварин, які перебували в умовах світлового балансу; " - відносно тварин протилежної статі.

При застосуванні МЕЛ спостерігали більш збалансовану активність ензимів АОС. У динаміці розвитку НМ активність СОД і КАТ зростала, більшою мірою в самиць, що могло бути результатом меншої депресії за умов реалізації антиоксидантних властивостей МЕЛ. При використанні МЕЛ активнішою була участь ензимів глутатіонового ряду. Активність ГР була більшою, ніж без корекції, зокрема на 1 та 24 год НМ у самців це становило, відповідно, 75 та $100 \%$ $(p<0,05)$, а в самиць - 41 і $47 \%$ ( $p<0,05)$. Варто зазначити, що при застосуванні МЕЛ активність ГР на 24 год НМ була достовірно вищою, ніж за умов світлового балансу, як у самців, так і в самиць (на 33 та $22 \%$ відповідно, р<0,05). Це демонструвало меншу депресію ГР за умов реалізації антиоксидантних ефектів гормону пінеальної залози, введеного ззовні [3, 4]. Активність ГП на етапі гіперадреналінемії в самців (1 год НM) була нижчою, ніж при світловому балансі (на $17 \%$, p <0,05), що відображало меншу активність перекисоутворення і підтверджувалося аналогічною закономірністю стосовно активності КАТ. Про кращий стан глутатіонової ланки антиоксидантного захисту свідчив достовірно більший, ніж за відсутності корекції, вміст сульфгідрильних груп. При застосуванні МЕЛ показник самців достовірно перевищував такий в особин, які перебували в умовах світлового балансу (на 1 та 24 год НM - 13 і $44 \%, p<0,05$ ) (табл. 2).

Про кращу збалансованість прооксидантноантиоксидантних процесів при застосуванні МЕЛ свідчив АПІ. Якщо в самців його значення в динаміці розвитку НМ на тлі перманентного освітлення зменшилося в 3,0 рази (24 год спостереження), а в самиць - у 2,1 раза, то при використанні МЕЛ у самців АПІ знизився лише в 1,7 раза, а в самиць - в 1,4 раза (в усіх випадках p<0,001). Про менший метаболічний дисбаланс за умов реалізації кардіотоксичного ефекту адреналіну свідчив той фракт, що динаміка АП була аналогічною такій при світловому балансі. Варто зазначити, що в самиць значення АПІ на 1 та 24 год розвитку НМ на тлі МЕЛ статистично було аналогічне такому, яке реєстрували за умов світлового балансу. В самців таку закономірність спостерігали лише на 1 год розвитку НМ, але на 24 год експерименту значення АПІ при застосуванні МЕЛ усе ж таки виявилося нижчим за порівнюване на 40 \% $(p<0,05)$, що відображало меншу, ніж у самиць, есрективність препарату (табл. 3). Показники самиць, що відображали більшу кардіопротекторну есективність мелатоніну на метаболічному рівні, можна пояснити активнішою участю ензимів системи глутатіону, особливо ГП. Тому при використанні МЕЛ вміст ДК у міокарді самців був вищим, ніж у самиць, зокрема на 1 год розвитку НМ - на $11 \%(p<0,05)$, на 24 год - на $18 \%(p<0,05)$, а МДА - на 5 та $13 \%(p<0,05)$ відповідно. При цьому активність СОД на $16 \%$ переважала значення самців $(p<0,05)$, ГП - на $19 \%(p<0,05)$.

Загалом проведений аналіз показав позитивний вплив екзогенного мелатоніну на перебіг некрозу міокарда в щурів, які перебували в умовах перманентного освітлення, і більшу чутливість серця самиць до такого впливу.

ВИСНОВОК. Застосування екзогенного мелатоніну для корекції його дефріциту при перманентному освітленні має позитивний вплив на 
Таблиця 2 - Активність антиоксидантної системи міокарда щурів при розвитку

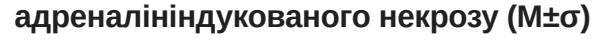

\begin{tabular}{|c|c|c|c|c|}
\hline Показник & Стать & $\begin{array}{c}\begin{array}{c}\text { Контроль } \\
(n=6)\end{array} \\
\end{array}$ & $\begin{array}{c}\text { НM (1 год) } \\
(n=6)\end{array}$ & $\begin{array}{c}\text { НМ (24 год) } \\
(n=6)\end{array}$ \\
\hline \multicolumn{5}{|c|}{ Світловий баланс } \\
\hline \multirow{2}{*}{$\begin{array}{l}\text { СОД, } \\
\text { ум. од./кг }\end{array}$} & $0^{x}$ & $0,42 \pm 0,01$ & $0,55 \pm 0,01^{*}$ & $0,32 \pm 0,02^{*}$ \\
\hline & 우 & $0,39 \pm 0,01$ & $0,49 \pm 0,03^{*}$ & $0,38 \pm 0,01$ \\
\hline \multirow{2}{*}{$\begin{array}{l}\text { КАТ, } \\
\text { мкат/кг }\end{array}$} & $\sigma^{x}$ & $0,97 \pm 0,03$ & $1,56 \pm 0,09^{*}$ & $3,43 \pm 0,29 * \#$ \\
\hline & 우 & $0,86 \pm 0,04$ & $1,45 \pm 0,11^{*}$ & $2,33 \pm 0,31^{\star \#}$ \\
\hline \multirow{2}{*}{$\begin{array}{l}\text { SH-групи, } \\
\text { ммоль/кг }\end{array}$} & $0^{x}$ & $2,48 \pm 0,08$ & $1,61 \pm 0,09^{*}$ & $0,90 \pm 0,04^{\star \#}$ \\
\hline & q & $2,42 \pm 0,07$ & $1,90 \pm 0,08^{*}$ & $1,45 \pm 0,06^{* \#}$ \\
\hline \multirow{2}{*}{$\begin{array}{l}\text { ГР, } \\
\text { ммоль/(хв·кг) }\end{array}$} & $0^{x}$ & $0,27 \pm 0,01$ & $0,18 \pm 0,01^{*}$ & $0,15 \pm 0,01^{*}$ \\
\hline & 우 & $0,31 \pm 0,01$ & $0,21 \pm 0,01^{*}$ & $0,18 \pm 0,01^{*}$ \\
\hline \multirow{2}{*}{$\begin{array}{l}\text { ГП, } \\
\text { ммоль/(хв·кг) }\end{array}$} & $0^{x}$ & $0,42 \pm 0,01$ & $0,56 \pm 0,02^{*}$ & $0,35 \pm 0,01^{*}$ \\
\hline & 우 & $0,39 \pm 0,01$ & $0,49 \pm 0,02^{*}$ & $0,38 \pm 0,01$ \\
\hline \multicolumn{5}{|c|}{ Перманентне освітлення } \\
\hline \multirow{2}{*}{$\begin{array}{l}\text { СОД, } \\
\text { ум. од./кг }\end{array}$} & $0^{x}$ & $0,57 \pm 0,03^{\wedge}$ & $0,41 \pm 0,03^{\star \wedge}$ & $0,23 \pm 0,02^{* \wedge}$ \\
\hline & 우 & $0,47 \pm 0,04$ & $0,35 \pm 0,02^{\star \wedge}$ & $0,29 \pm 0,01^{\star \wedge}$ \\
\hline \multirow{2}{*}{$\begin{array}{l}\text { КАТ, } \\
\text { мкат/кг }\end{array}$} & $0^{x}$ & $1,30 \pm 0,11^{\wedge}$ & $3,62 \pm 0,33^{\star \wedge}$ & $2,08 \pm 0,18^{\star \wedge}$ \\
\hline & 우 & $1,01 \pm 0,15$ & $2,70 \pm 0,13^{\star \wedge}$ & $2,12 \pm 0,08^{*}$ \\
\hline \multirow{2}{*}{$\begin{array}{l}\text { SH-групи, } \\
\text { ммоль/кг }\end{array}$} & $\sigma^{\pi}$ & $1,92 \pm 0,08^{\wedge}$ & $0,87 \pm 0,04^{\star \wedge \#}$ & $0,59 \pm 0,03^{\star \wedge \#}$ \\
\hline & o & $2,10 \pm 0,08^{\wedge}$ & $1,35 \pm 0,04^{\star \wedge \#}$ & $0,97 \pm 0,05^{\star \wedge \#}$ \\
\hline \multirow{2}{*}{$\begin{array}{l}\Gamma \mathrm{P}, \\
\text { ммоль/(Хв·кг) }\end{array}$} & $0^{x}$ & $0,33 \pm 0,01^{\wedge}$ & $0,12 \pm 0,01^{\star \wedge \#}$ & $0,10 \pm 0,01^{\star \wedge \#}$ \\
\hline & o & $0,35 \pm 0,01^{\wedge}$ & $0,17 \pm 0,01^{\star \wedge \#}$ & $0,15 \pm 0,01^{\star \#}$ \\
\hline \multirow{2}{*}{$\begin{array}{l}\text { ГП, } \\
\text { ммоль/(хв·кг) }\end{array}$} & $0^{x}$ & $0,51 \pm 0,02^{\wedge \#}$ & $0,64 \pm 0,02^{\star \wedge}$ & $0,24 \pm 0,01^{\star \wedge \#}$ \\
\hline & 우 & $0,44 \pm 0,01^{\wedge \#}$ & $0,58 \pm 0,02^{\star \wedge}$ & $0,30 \pm 0,02^{\star \wedge \#}$ \\
\hline \multicolumn{5}{|c|}{ Перманентне освітлення+мелатонін } \\
\hline \multirow{2}{*}{$\begin{array}{l}\text { СОД, } \\
\text { ум. од./кг }\end{array}$} & $0^{x}$ & $0,37 \pm 0,01^{\wedge}$ & $0,52 \pm 0,02^{\star \#}$ & $0,45 \pm 0,02^{\star \wedge \#}$ \\
\hline & 우 & $0,36 \pm 0,02$ & $0,56 \pm 0,02^{\star \wedge \#}$ & $0,52 \pm 0,02^{\star \wedge \#}$ \\
\hline \multirow{2}{*}{$\begin{array}{l}\text { КАТ, } \\
\text { мкат/кг }\end{array}$} & $0^{x}$ & $0,89 \pm 0,03^{\wedge \#}$ & $1,63 \pm 0,21^{*}$ & $2,82 \pm 0,21^{\wedge \star}$ \\
\hline & 우 & $0,80 \pm 0,03^{\wedge \#}$ & $1,52 \pm 0,27^{\star}$ & $2,62 \pm 0,20 *$ \\
\hline \multirow{2}{*}{$\begin{array}{l}\text { SH-групи, } \\
\text { ммоль/кг }\end{array}$} & $0^{x}$ & $2,38 \pm 0,17$ & $1,82 \pm 0,13^{\star \wedge}$ & $1,30 \pm 0,08^{\star \wedge}$ \\
\hline & q & $2,45 \pm 0,14$ & $1,95 \pm 0,10^{\star}$ & $1,67 \pm 0,07^{\star \wedge}$ \\
\hline \multirow{2}{*}{$\begin{array}{l}\text { ГР, } \\
\text { ммоль/(хв·кг) }\end{array}$} & $0^{x}$ & $0,34 \pm 0,01^{\wedge}$ & $0,21 \pm 0,01^{*}$ & $0,20 \pm 0,01^{\star \wedge}$ \\
\hline & क & $0,32 \pm 0,01$ & $0,24 \pm 0,01^{*}$ & $0,22 \pm 0,01^{\star \wedge}$ \\
\hline \multirow{2}{*}{$\begin{array}{l}\Gamma П, \\
\text { ммоль/(хв·кг) }\end{array}$} & $0^{x}$ & $0,38 \pm 0,01^{\wedge *}$ & $0,48 \pm 0,02^{\star \wedge}$ & $0,36 \pm 0,01^{\#}$ \\
\hline & 우 & $0,33 \pm 0,01^{\wedge \#}$ & $0,50 \pm 0,02^{*}$ & $0,43 \pm 0,02^{\star \wedge \#}$ \\
\hline
\end{tabular}

Таблиця 3 - Антиоксидантно-прооксидантний індекс міокарда щурів

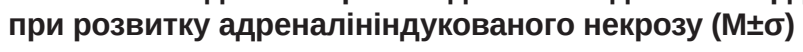

\begin{tabular}{|c|c|c|c|c|}
\hline Показник & Стать & $\begin{array}{c}\text { Контроль } \\
(\mathrm{n}=6)\end{array}$ & $\begin{array}{l}\text { НМ (1 год) } \\
(n=6)\end{array}$ & $\begin{array}{c}\mathrm{HM} \mathrm{(24} \mathrm{год)} \\
(\mathrm{n}=6)\end{array}$ \\
\hline \multicolumn{5}{|c|}{ Світловий баланс } \\
\hline \multirow[t]{2}{*}{ АПІ } & $0^{x}$ & $0,77 \pm 0,03^{\#}$ & $0,41 \pm 0,03^{*}$ & $0,60 \pm 0,06^{*}$ \\
\hline & 우 & $0,67 \pm 0,02^{\#}$ & $0,42 \pm 0,04^{*}$ & $0,50 \pm 0,08^{*}$ \\
\hline \multicolumn{5}{|c|}{ Перманентне освітлення } \\
\hline \multirow[t]{2}{*}{ AПI } & $0^{x}$ & $0,68 \pm 0,08^{\wedge}$ & $0,60 \pm 0,05^{\wedge \#}$ & $0,23 \pm 0,02^{\star \wedge}$ \\
\hline & 우 & $0,59 \pm 0,10$ & $0,49 \pm 0,03^{\wedge \#}$ & $0,28 \pm 0,01^{\star \wedge}$ \\
\hline \multicolumn{5}{|c|}{ Перманентне освітлення+мелатонін } \\
\hline \multirow[t]{2}{*}{ AПI } & $0^{x}$ & $0,73 \pm 0,02^{\wedge \#}$ & $0,37 \pm 0,05^{\star}$ & $0,43 \pm 0,03^{\star \wedge}$ \\
\hline & 우 & $0,65 \pm 0,04^{\#}$ & $0,36 \pm 0,05^{*}$ & $0,45 \pm 0,04^{*}$ \\
\hline
\end{tabular}

розвиток адреналініндукованого некрозу міокар- антиоксидантів у динаміці розвитку некротичного да, що підтверджується нижчою, ніж без такої процесу, меншим відсотком некротизованих корекції, активацією пероксидного окиснення кардіоміоцитів. Більш чутливими до позитивного ліпідів, менш вираженою депресією системи впливу екзогенного мелатоніну є самиці щурів. 


\section{СПИСОК ЛІТЕРАТУРИ}

1. Opie L. H. Melatonin has multiorgan effects / L. H. Opie, S. Lecour // Eur. Heart J. Cardiovasc. Pharmacother. - 2016. - 2 (4). - P. 258-265.

2. Ma S. Melatonin attenuates cardiac reperfusion stress by improving OPA1-related mitochondrial fusion in a Yap-Hippo pathway-dependent manner / S. Ma, Z. Dong // J. Cardiovasc. Pharmacol. - 2019. - 73 (1). P. 27-39.

3. Roles of mitochondrial dynamics modulators in cardiac ischaemia/reperfusion injury / Chayodom Maneechote, Siripong Palee, Siriporn C. Chattipakorn, Nipon Chattipakorn // J. Cell. Mol. Med. - 2017. - 21 (11). P. 2643-2653.

4. Lochner A. Melatonin and cardioprotection against ischaemia/reperfusion injury: What's new? A review / A. Lochner, E. Marais, B. Huisamen // J. Pineal Res. 2018 - 65 (1). - P. 12490.

5. Nduhirabandi F. Melatonin in heart failure: $A$ promising therapeutic strategy? / F. Nduhirabandi, J. Gerald // Molecules. - 2018. - 23 (7). - P. 1819.

6. Гавриллов В. Б. Спектрофротометрическое определение содержания гидроперекисей липидов в плазме крови / В. Б. Гавриллов, М. И. Мишкорудная // Лаб. дело. - 1983. - № 3. - С. 33-35.

7. Андреева Л. И. Модисрикация метода определения перекисей липидов в тесте с тиобарбитуровой кислотой / Л. И. Андреева, Л. А. Кожемякин, А. А. Кишкун // Лаб. дело. - 1988. - № 11. - С. 41-43.

8. Чевари С. Роль супероксиддисмутазы в окислительных процессах клетки и метод определения ее в биологическом материале / С. Чевари, И. Чаба, й. Сокей // Лаб. дело. - 1985. - № 11. - С. 678-681.

9. Королюк М. А. Метод определения активности каталазы / М. А. Королюк, Л. И. Иванова, И. Г. Майорова // Лаб. дело. - 1988. - № 1. - С. 16-19.

10. Кругликова Г. О. Глутатіонпероксидазна та глутатіонредуктазна активність печінки щурів після введення селеніту натрію/Г.О.Кругликова, Ц. М. Штутман // Укр. біохім. журн. - 1976. - № 48 (2). - С. 227233.

11. Веревкина Н. В. Колориметрический метод определения SH-групп и SS-связей в белках при помощи 5,5-дитиобис (2-нитробензоновой) кислоты / Н. В. Веревкина, А. И. Точилкин, Н. А. Попова // Современные методы в биохимии. - М. : Медицина, 1977. - C. 223-231.

12. Хара М. Р. Перекисне окиснення ліпідів у міокарді при розвитку некротичного процесу на тлі мелатоніну та різної активності гонад / М. Р. Хара, Л. І. Кучирка // Клініч. та експерим. патологія. -2014. № 4 (50). - С. 148-151.

13. Хара М. Р. Статеві відмінності метаболічних змін в міокарді при розвитку некротичного процесу на тлі мелатоніну / М. Р. Хара, О. В. Шкумбатюк // Актуальные проблемы транспортной медицины. 2014. - 2 (36-II), № 2. - С. 47-52.

14. Перекисное окисление липидов: противоречия проблемы / В. К. Казимирко, Л.Н.Иваницкая, В. В. Кутовой [и др.] // Укр. ревматол. журн. - 2014. № 3 (57). - С. 13-17.

\section{REFERENCES}

1. Opie, L.H., \& Lecour, S. (2016) Melatonin has multiorgan effects. Eur. Heart J. Cardiovasc. Pharmacother., 2 (4), 258-265.

2. Ma, S., \& Dong, Z. (2019). Melatonin attenuates cardiac reperfusion stress by improving OPA1-related mitochondrial fusion in a Yap-Hippo pathway-dependent manner. J. Cardiovasc. Pharmacol., 73 (1), 27-39.

3. Chayodom Maneechote, Siripong Palee, Siriporn C. Chattipakorn, Nipon Chattipakorn (2017). Roles of mitochondrial dynamics modulators in cardiac ischaemia/ reperfusion injury. J. Cell. Mol. Med., 21 (11), 2643-2653.

4. Lochner, A., Marais, E., \& Huisamen, B. (2018). Melatonin and cardioprotection against ischaemia/ reperfusion injury: What's new? A review. J. Pineal. Res., 65 (1), 12490.

5. Nduhirabandi, F. (2018) Melatonin in heart failure: A promising therapeutic strategy? Molecules, 23 (7), 1819.

6. Gavrillov, V.B., \& Mishorudnaya, M.I. (1983). Spektrophotometricheskoye opredelenie soderzhania hydroperekisey lipidov v plazme krovi [Spectrophotometric determination of lipid hydroperoxide content in blood plasma]. Laboratornoe delo - Laboratory Work, 3, 33-35 [in Russian].

7. Andreeva, L.I., Kozhemyakin, L.A., \& Kishkun, A.A. (1988). Modifikatsiya metoda opredeleniya perekisey lipidov $v$ teste $s$ tiobarbiturovoy kislotoy [Modification of the method of determination of lipid peroxides in the test with thiobarbituric acid]. Laboratornoe delo - Laboratory Work, 11, 41-43 [in Russian].

8. Chevari, S., Chaba, I., \& Sokey J. (1985). Rol superoxiddismutazy $v$ okislitelnykh protsessakh kletki i metod opredeleniya ee $v$ biologicheskom materiale [The role of superoxide dismutase in the oxidative processes of the cell and the method of its determination in biological material]. Laboratornoe delo - Laboratory Work, 11, 678681 [in Russian].

9. Korolyuk, M.A., Ivanova, L.I., \& Mayorov, I.G. (1988). Metod opredeleniya aktivnisti katalazy [The method of determining the activity of catalase]. Laboratornoe delo - Laboratory Work, 1, 16-19 [in Russian].

10. Verevkina, N.V., Tochilkin, A.I., \& Popova, N.A. (1977). Kolorimetricheskiy metod opredeleniya SH-grupp iSS-svyazeypripomoshchi5,5-ditiobis (2-nitrobenzonovoi) kisloty [A colorimetric method for the determination of $\mathrm{SH}$ groups and SS bonds in proteins by 5.5-dithiobis (2-nitrobenzoic) acid]. Modern methods in biochemistry. Moscow: Meditsina [in Russian].

11. Kruhlykova, H.O., \& Stutman, Ts.M. (1976). Hlutationperoksydazna ta hlutationreduktazna aktyvnist pechinky shchuriv pislia vvedennia selenitu natriu [Glutathione peroxidase and glutathione reductase activity of rat liver after administration of sodium selenite]. Ukr. biokhim. zhurn. - Ukrainian Biochem. Journ., 48 (2), 227-233 [in Ukrainian]. 
12. Khara, M.R., \& Kuchyrka, L.I. (2014). Perekysne okysnennia lipidiv u miokardi pry rozvytku nekrotychnoho protsesu na tli melatoninu ta riznoi aktyvnosti honad [Lipid peroxidation in the myocardium in development of necrotic process on the background of melatonin and different activity of the gonads]. Klin. ta eksperym. patol. Clinical and Experimental Pathology, 4 (50), 148-151 [in Ukrainian].

13. Khara, M.R., \& Shkumbatiuk, O.V. (2014). Statevi vidminnosti metabolichnykh zmin v miokardi pry rozvytku nekrotychnoho protsesu na tli melatoninu [Gender differences of metabolic changes in myocardium in the development of necrotic process on the background of melatonin]. Aktual. probl. transport. med. - Actual Problems of Transport Medicine, 2 (36-II), 47-52 [in Ukrainian].

14. Kazimirko, V.K., Ivanitskaya, L.N., Kutovoy, V.V., Dubkova, A.H., \& Silantieva, T.S. (2014). Perekisnoe okislenie lipidov: protivorechiya problemy [Lipid peroxidation: contradictions of the problem]. Ukr. revmat. zhurn. - Ukrainian Rheumatology Journal, 3 (57), 13-17 [in Russian].

\section{ГЕНДЕРНЫЕ АСПЕКТЫ КАРДИОПРОТЕКТОРНОЙ ЭФФЕКТИВНОСТИ МЕЛАТОНИНА ПРИ РАЗВИТИИ АДРЕНАЛИНИНДУЦИРОВАННОГО НЕКРОЗА МИОКАРДА НА ФОНЕ ПЕРМАНЕНТНОГО ОСВЕЩЕНИЯ}

\section{Резюме}

Вступление. Световой десинхроноз является важным фрактором риска развития ишемической болезни сердца, которая чаще возникает у мужчин. Повреждение миокарда в условиях стресса, вызванного нарушением режима освещения (его избытком), приводит к значительному дефициту эндогенного мелатонина, который обладает антиоксидантными свойствами. Это позволяет прогнозировать уменьшение негативного влияния стресса или катехоламинов на серце в условиях перманентного освещения при применении экзогенного мелатонина. На сегодняшний день недостаточно изучен вопрос гендерного отличия кардиопротекторных свойств мелатонина при нарушении активности пинеальной железы.

Цель исследования - изучить кардиопротекторную эфрфективность экзогенного мелатонина при развитии некроза миокарда на фоне перманентного освещения в зависимости от пола.

Методы исследования. В миокарде желудочков самцов и самок крыс определяли процент некротизированных кардиомиоцитов, активность перекисного окисления липидов и антиоксидантной системы при повреждении адреналином. Некроз миокарда вызывали путем введения адреналина (0,5 мг/ка, внутримышечно) на фроне перманентного освещения (10 дней освещения 500 люкс, 24 ч/сутки). Группу контроля составляли животные, которые находились в условиях изменения циклов день/ночь (12 ч освещения 500 люкс/12 ч освещения 0,5-1,0 люкс). Мелатонин (5 м2/ке, интраперитонеально) для корекции вводили за 1 ч до инъекции адреналина.

Результаты и обсуждение. При применении мелатонина развитие некроза миокарда характеризовалось меньшим процентом некротизированных кардиомиоцитов, меньшей, чем без коррекции, активацией перекисного окисления липидов, большей активностью супероксиддисмутазы и глутатионпероксидазы. О лучшем балансе прооксидантно-антиоксидантных прочессов свидетельствовало большее, чем без коррекции, значение антиоксидантно-прооксидантного индекса, особенно у самок. Эта закономерность демонстрировала положительное влияние экзогенного мелатонина и непрямо подтверждала его дефицит в условиях перманентного освещения.

Вывод. Применение экзогенного мелатонина для коррекции его дефицита при перманентном освещении положительно влияет на развитие адреналининдуцированного некроза миокарда, что подтверждается меньшей, чем без такой коррекции, активацией перекисного окисления липидов, менее выраженной депрессией системы антиоксидантов, меншим процентом некротизированных кардиомиоцитов. Самки крыс более чувствительны к положительному влиянию экзогенного мелатонина по сравнению с самцами.

КЛЮЧЕВЫЕ СЛОВА: перманентное освещение; некроз миокарда; свободнорадикальное окисление; половые отличия. 


\section{GENDER ASPECTS OF CARDIOPROTECTIVE EFFICIENCY OF MELATONIN AT THE DEVELOPMENT OF ADRENALINE-INDUCED MYOCARDIAL NECROSIS ON THE PERMANENT LIGHT BACKGROUND}

\section{Summary}

Introduction. Circadian rhythm disturbance is a risk factor for ischemic heart disease, which is more common in men. Disturbance of the lighting regime (its excess) leads to deficit of endogenous melatonin and its antioxidant properties. That allows one to predict a decrease in the negative effect of stress or catecholamines on the heart at permanent light for using exogenous melatonin. To date, the gender difference in cardioprotective properties of melatonin in conditions of impaired activity of the pineal gland is not well understood.

The aim of the study - investigation of the cardioprotective effect of exogenous melatonin in the development of myocardial necrosis on the background of permanent light depending on sex.

Research Methods. Adrenalin-induced myocardium necrosis $(M N)$ caused by adrenalin $(0.5 \mathrm{mg} / \mathrm{kg}$ intramuscular) on a background of permanent illumination (10 days, illumination 500 lux/24 hours). Percentage of necrotized cardiomyocytes (PNC), lipid peroxidation (LPO) and antioxidant system (AOS) activity were determined in the myocardium. Melatonin ( $5 \mathrm{mg} / \mathrm{kg}$, intraperitoneal) was administered 1 hour before adrenaline. Animals of control group were in condition of day/night balance (12 h illumination 500 Lux and 12 h illumination 0.5-1 Lux).

Results and Discussion. Development of MN at melatonin use was characterized by less PNC, less activity of LPO, higher activity of superoxide dismutase and glutathione peroxidase. The better balance of prooxidantantioxidant processes was evidenced by the value of the antioxidant-prooxidant index, especially in females. This pattern demonstrated the positive effect of exogenous melatonin and indirectly confirmed its deficiency under conditions of permanent illumination.

Conclusion. Melatonin has a positive effect on the development of adrenaline-induced myocardial necrosis on a background of permanent illumination, which is confirmed by less percentage of necrotized cardiomyocyte, less activity of lipid peroxidation, less depression of the antioxidant system. Female rats are more sensitive to the positive effect of exogenous melatonin compared to males.

KEY WORDS: permanent illumination; myocardial necrosis; free radical oxidation; sex difference. майдан Волі, 1, Тернопіль, 46001, Україна, e-mail: khara_m@ukr.net. 